\title{
Vhavenda Herbal Remedies as Sources of Antihypertensive Drugs: Ethnobotanical and Ethnopharmacological Studies
}

\author{
Gundo Mudau (D), Samuel Odeyemi $\mathbb{D}^{\text {, }}$, and John Dewar \\ Department of Life and Consumer Sciences, College of Agriculture and Environmental Sciences, University of South Africa, \\ Johannesburg 1709, South Africa \\ Correspondence should be addressed to Samuel Odeyemi; odeyesw@unisa.ac.za
}

Received 21 October 2020; Revised 11 November 2020; Accepted 30 November 2020; Published 11 December 2020

Academic Editor: Marcio Carocho

Copyright (c) 2020 Gundo Mudau et al. This is an open access article distributed under the Creative Commons Attribution License, which permits unrestricted use, distribution, and reproduction in any medium, provided the original work is properly cited.

\begin{abstract}
Hypertension is a dominant risk factor for the development of cardiovascular, kidney, and eye diseases. In Africa, it increasingly leads to hospitalisation and a strain on the public health system. However, rather than modern medicine, African traditional healers are the first choice for most South Africans. Therefore, this study is aimed at gathering information on herbal remedies traditionally used for the treatment of high blood pressure in Vhavenda, South Africa, and comparing this information with reports in the literature regarding plants used to manage high blood pressure. An ethnobotanical survey was carried out in Vhembe district and its environs with 53 herbalists and indigenous people aged between 36 and 66 years from January to October 2019 using a semistructured questionnaire. The plants were collected with each respondent; they were authenticated and kept in herbarium. A total of 51 different plants were mentioned as being most commonly used for hypertension treatment. Of these, 44 plants were identified, with those from the Fabaceae family followed by plants from the Celastraceae family being commonly mentioned. Of these, the Elaeodendron transvaalense, Tabernaemontana elegans, Elephantorrhiza elephantina, and Aloe vossii were commonly cited species. According to the literature data, most of the identified plants are yet to be scientifically investigated for the treatment of hypertension, whereas only preliminary investigations have been carried out on other plants, suggesting that these preliminary investigations may have highlight promising antihypertensive activities in vitro that are indicative of their potential as antihypertensive drugs. Therefore, there is a need to scientifically investigate the antihypertensive potentials of these plants as a potential source of antihypertensive treatment and compounds.
\end{abstract}

\section{Introduction}

Hypertension is increasing at an alarming rate as a major public health concern after infection with the human immunodeficiency virus (HIV) and tuberculosis (TB). It is becoming one of the common cardiovascular diseases and a major health concern worldwide [1]. The two types of hypertension viz systolic and diastolic, graded as to patient blood pressure (BP): grade I or mild (BP 140-159/90-99 mmHg), grade II or moderate (BP 160-179/100-109 $\mathrm{mmHg}$ ), and grades III and IV or severe (BP $>180-210 / 110-120 \mathrm{mmHg}$ ) [2]. The exact causes of high blood pressure are unknown, but several risk factors such as family history, smoking, extensive use of alcohol, being overweight or obese, high sodium intake, high sugar intake, or lack of physical activity have been linked to the development of hypertension [3]. The incidence of hypertension has been reported mainly in individuals over 50 years in age, although there have been a few reports involving younger patients [4]. There are also reports that suggest that other conditions such as kidney failure, insulin resistance, atherosclerosis, cardiovascular diseases, and nervous system problems cause or exacerbate high blood pressure $[5,6]$. There are different treatment regimens for hypertension, but these are associated with side effects, and hence, there is still a need for alternative treatment modalities. In this regard, different societies have their own systems in place to maintain and restore well-being, including traditional medicine that are of great importance as research has shown that their therapeutic properties are associated with secondary plant metabolites which treat the disease 
effectively with fewer or no side effects compared to the use of synthetic drugs [7].

A recent report suggests that more than three quarters of the world population depends on traditional medicine [8]. In Africa, the use of traditional medicine is popular due to trust and belief in its efficacy and dissatisfaction shown towards modern medicine [9]. Traditional medicine was in existence in Africa long before western medicine, and it is believed to link with "ubuntu," connecting the patient to the land and to embrace nature [10]. Thus, traditional medicine is an integral and important part of the African heritage with this system developed by the society and passed on from one generation to the next in various forms $[11,12]$.

In Africa, traditional healers are believed to heal the physical and psychospiritual unwellness of an individual, reflecting a holistic approach to healing and treatments $[9$, 13]. This has led to a dependence on traditional healers such that they provide health services to over $80 \%$ of the population in rural communities due to their accessibility and affordability, and they have become the first choice for treatment for many people [14-16]. The relatively small number of health facilities and the associated delays in processing and treatment have influenced rural communities in their choice of traditional medicine rather than modern health care $[10,17]$. In Thailand, the government has developed a healing system called "traditional Thai medicine" involving a health policy designed to reduce the use of expensive modern medicines that is linked to a scientific approach of 4-year curricula for training programs that culminate in a bachelor's degree [18]. Zimbabwe has also taken the initiative where they have their own Traditional Medical Practitioner Act which integrates traditional and modern medicines [19]. The South African government is attempting to close the gap between modern medicine and traditional medicine by providing complementary and alternative health services $[20,21]$. In 2007, the South African government passed the Traditional Health Practitioner Act No. 22 so that in May 2014, sections of this Act provided more autonomy to the Traditional Health Practitioner Council of South Africa [22-24]. In light of these developments, this study is aimed at documenting indigenous knowledge on the herbal remedies used by the people of Vhembe District, Thulamela, South Africa, for the treatment of hypertension.

\section{Methods}

\subsection{Ethnobotanical Survey}

2.1.1. The Study Area and Population. Vhembe is one of the five districts in the Limpopo Province, South Africa (SA), located in the far northern part of South Africa sharing borders with Zimbabwe and Mozambique. It covers a surface area of $25,596 \mathrm{~km}^{2}$ with a population of $1,393,949$ in 2016 (Figure 1), is a predominantly rural, cultural hub, and is a catalyst for agricultural and tourism development $[25,26]$. The Vhembe district consists of three ethnics groups with Thohoyandou as the capital. It is the former Tsonga homeland of Gazankulu with Hlanganani and Malamulele. It has a population of 800,000 Venda-speaking, 400,000 Tsonga-speak- ing, and 27,000 Northern Sotho-speaking citizens [27]. Interviews with participants in this study were conducted at Thulamela municipality, Thohoyandou town which has a population of 618,462 and a growth rate of $0.62 \%$ (20012011) [27]. The study area falls into the category of villages with a high prevalence of hypertension.

2.1.2. Ethics Approval. Consent to enter Tshififi village was obtained from the headman of the Tshikalange Tribal Authority. This allowed the proposed study to proceed within the jurisdiction of Tshififi and nearby areas. In practice, the respondents were each provided with a consent form that was approved by the University of South Africa's Ethics Committee (REC Reference No. 2018/CAES/146) before the study was explained to them. Each respondent who agreed to participate in the study then signed the consent form before the interviews were conducted in the knowledge that their anonymity was assured. Collected plant samples were authenticated at the Horticulture center, University of South Africa, Science Campus, and the voucher specimen was deposited.

2.1.3. Data Collection. Since high blood pressure is a common health problem in the study area, the traditional healers were not asked for information on their diagnostic criteria. The survey was conducted during January and October 2019 and involved conducting face-to-face interviews with each respondent-in the local dialect where the respondent answered 12 open-end questions so that the researcher could collate demographic details of the traditional healers as well as the plants that they used to manage hypertension. The demographic information about each respondent included their age, gender, educational background, and locality. The information about the plants includes the vernacular names of the plants, parts used, methods of preparation of the recipes, route of administration, dosage, duration of treatment, and the management of other diseases for which the plants are used. The study relied on the recommendations of the headman, who identified the traditional healers and other qualified respondents.

2.1.4. Plant Collection and Identification. A good rapport was established between the researcher and the respondents and with their assistance; plant species were collected during several visits over the course of the study. The selected respondents were those often-assisting traditional healers in plant collection from their natural habitat. A broad approach was used to correctly identify collected plant materials. This involved (i) comparison against samples in the Unisa Herbarium, (ii) against data from the literature, and (iii) consultation with botanists from within the Unisa College of Agriculture and Environmental Science (CAES) laboratories, the Unisa Department of Life and Consumer Sciences, and the Unisa Horticulture Centre. Consulted data bases included the PlantZAfrica database (http://pza.sanbi.org/), SANBI infobases (https://www.sanbi.org/resources/infobases/), and Vhenda inventory [28]. The voucher specimens of all the collected plant species were deposited in the Herbarium at the University of South Africa, Science Campus. 


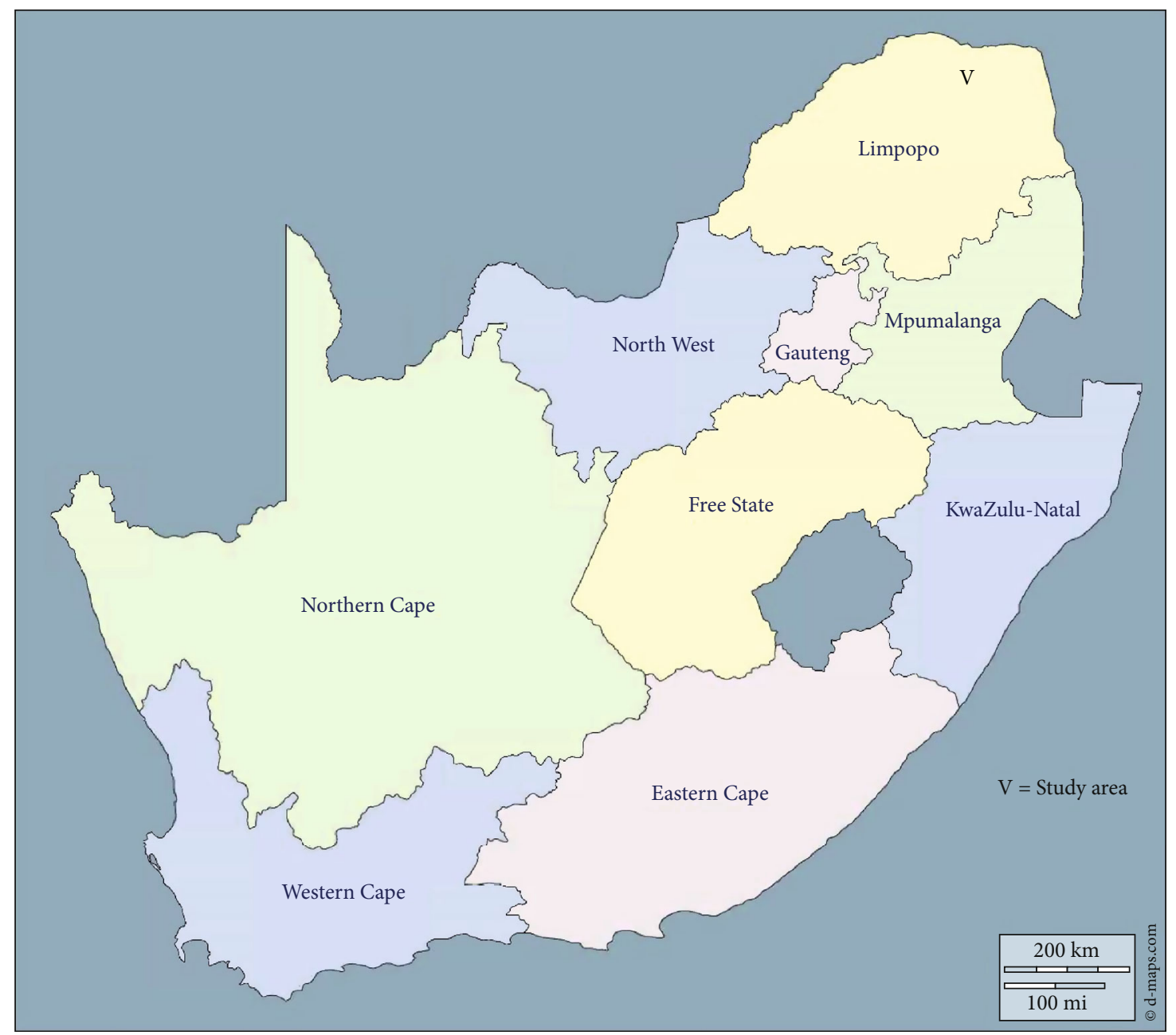

FIGURE 1: Study area: Vhembe district located in Limpopo province, South Africa.

2.1.5. Data Processing and Analysis. Data acquired from the questionnaire were uploaded onto a Microsoft Excel (365) spreadsheet and analyzed using both descriptive and inferential statistics. Percentages were used to analyse the respondents' sociodemographic data, and the relative frequency of citation (RFC) was used to determine the relative use of the plants.

(1) Relative Frequency of Citation (RFC). This was calculated using the formula:

$$
\mathrm{RFC}=\frac{\mathrm{Fc}}{N},
$$

where $\mathrm{Fc}$ is the number of respondents who cited a species and $N$ is the total number of the respondents. The RFC was used to determine the importance of a particular plant species $(0<\mathrm{RFC}<1)$.

2.2. Literature Review. ScienceDirect, PubMed, and Google Scholar databases were used to compare the literature reporting on medicinal plants showing antihypertensive activity against the data obtained in the survey. This was carried out using keywords (antihypertensive plants, ethnobotanical survey, medicinal plants, ethnomedicine, ethnobotany, herbal medicine, and treatment of hypertension). To obtain information on plants used in South Africa, the word "South Africa" was inserted and combined with the different keywords as indicated earlier.

\section{Results}

\subsection{Ethnobotanical Survey}

3.1.1. Demographic Information of the Participants and Their Knowledge of Hypertension. A total of 60 respondents were approached to participate in this study, and of these, 53 agreed to participate including 23 traditional healers. As shown in the sociodemographic data of the participants (Table 1), the participants were based across 11 villages, $47.2 \%$ of the participants were males and $52.8 \%$ were females. All of the participants spoke Tshivenda, and most worship the ancestors (92.5\%). The majority of the participants (43.4\%) were within the age range of 56 to 66 years suggesting that the older age groups are the custodians of traditional knowledge. About forty percent (39.6\%) of the participants 


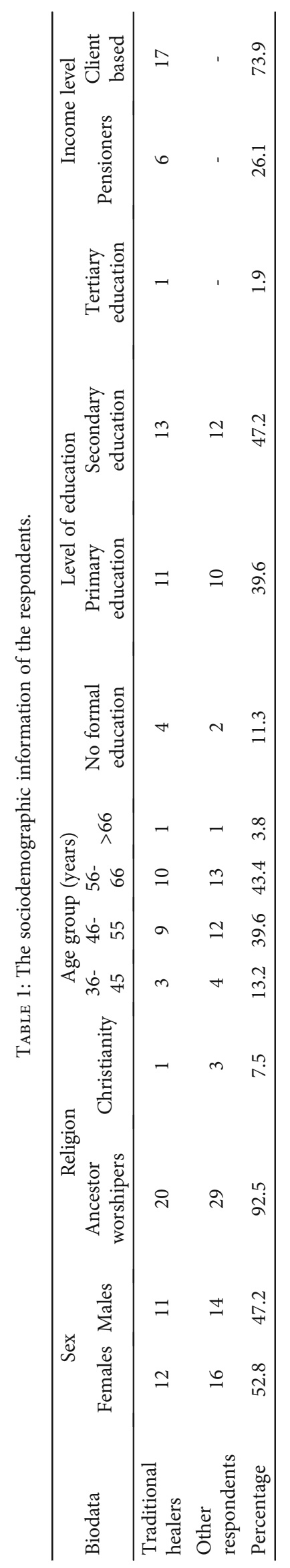


had primary education, $47.2 \%$ secondary education, $1.9 \%$ tertiary education, and $11.3 \%$ had no formal education. None of the participants in this study was employed, and with the exception of one healer who used eight plant species and another who used 12 plant species, all of the participants used up to six plant species to treat hypertension. All the traditional healers that participated in this survey got their trainings through family knowledge particularly from ancestors.

3.1.2. Diversity of Plants Used for the Treatment of Hypertension. The information on the medicinal plants used for traditional management of hypertension is presented in Table 2. A total of 51 plants species belonging to 30 families were reported as part of the hypertension treatment program in this study. The family distribution is shown in Figure 2. Members of the Fabaceae family were most commonly mentioned (10 times) followed by members of the Celastraceae family (3 times). Most of the plant parts used in the treatment decoction involved the roots, leaves, stems, and/or a combination of these parts (Figure 3). A decoction was prepared by drying, crushing, and soaked the plant part in water before a teacup of decoction was orally administered two or three times a day, while the majority (49\%) of the respondents use the roots followed by the leaves with $40 \%$ usage (Figure 3).

3.1.3. Frequently Collected Plant Species. The RFC value of each reported medicinal plant species was calculated and summarized (Table 2). The plants with $50 \%$ or more citations $(\mathrm{RFC} \geq 0.5)$ were considered to be relatively important plants. In total, 3 plants were cited frequently by the respondents: Mukuvhazwivhi/Mulumanamana (Elaeodendron transvaalense), Muhatu (Tabernaemontana elegans), and Gumululo (Elephantorrhiza elephantina) with RFC values of $0.71,0.52$, and 0.52 , respectively.

3.2. Analysis of Literature Review. From the review of literature, 62 families comprising to 139 plant species were reportedly used for the treatment of hypertension and related symptoms (Suppl. Table 1). The Asteraceae $(n=16)$ is the most commonly reported family, followed by the Fabaceae $(n=9)$, Rutaceae $(n=8)$, Anacardiaceae $(n=7)$, and Lamiaceae $(n=7)$ with the indicated number of plant species, respectively. The plants that were frequently cited in the literature are Psidium guajava L., Catharanthus roseus (L.), Citrullus lanatus (Thunb.), Agave americana (L.), Hypoxis hemerocallidea (Fisch.), Musa acuminata, Clausena anisata (Willd.), and Ruta graveolens.

3.2.1. Comparative Analysis of the Ethnobotanical Survey with Literature Data. Comparing the antihypertensive plants in the ethnobotanical research with data from the literature revealed that $14 \%$ have been reported from the medicinal plants in the survey as antihypertensives. Furthermore, there are similarities between the ethnobotanical survey and data from the literature in terms of the most frequently cited families. The Fabaceae is the dominantly represented family whereas the most frequently reported plant is the C. sativa both in the survey and literature data. In contrast, $88 \%$ of the plant species identified in the present survey have not been reported previously in South Africa as antihypertensive plants. These newly reported plants include Elaeodendron transvaalense, Tabernaemontana elegans, and Elephantorrhiza elephantina.

3.2.2. Plant-Derived Compounds Reported for Antihypertensive Activity. A quick summary obtained from the literatures clearly identified different classes of compounds. Some of these compounds have been evaluated for their antihypertensive activities using in vitro or in vivo assays belonging to different classes such as phenolics, flavonoids, glycosides, alkaloids, saponins, tannins, triterpenes, and peptides (Suppl. Table 1). Phenolics $(n=44)$ are the most commonly reported group of compounds identified with antihypertensive activities, followed by flavonoids $(n=31)$ and alkaloids $(n=27)$.

3.2.3. Reported Mechanisms of the Herbal Remedies and Extracts towards the Alleviation of Hypertension. In the literature, most of the plants used for the management of hypertension carry out their antihypertensive activity through the inhibition of angiotensin-converting enzyme (ACE), reduction of oxidative stress, vasorelaxation via the nitric oxideguanylyl cyclase pathway, and a prostaglandin-mediated mechanism as well as anti-inflammatory activities. Other reported mechanisms include the activation of the ATPsensitive potassium channel, lowering of systolic blood pressure, EDRF-dependent or -independent pathways, endothelium-dependent vasorelaxation, a $\beta 1$ agonist effect and direct vasoconstrictive effect, lowering left ventricular systolic pressure, reduction of systemic blood pressure and heart rate, inhibition of oxytocin-induced contraction, nitric oxide and angiotensin II-like activities, redox-sensitive phosphorylation of eNOS via the PI3-kinase pathway, and inhibition of $\mathrm{Na}+$ and $\mathrm{K}+$ reabsorption. Supplementary Table 1 shows that 24 plants inhibit ACE only, and 38 plants possess both antioxidant and anti-inflammatory activities, while 59 plant species have not been investigated for their mechanism of action.

\section{Discussion}

4.1. Demographic Information. As there were more females than males interviewed in the current survey, the predominance of women in relation to men can probably be ascribed to the involvement of men in other fields of work or the interview period such as when men were not at home. This is in agreement with the findings of a comparable study conducted in the Western Cape, South Africa [1], that reported a higher proportion of female over male respondents. The higher number of females to males in this study is similar to previous reports $[1,102,103]$, but some authors also provided contrasting reports by suggesting that parents usually prefer to transfer indigenous knowledge to boys [104]. It will be fair to say that not all the respondents are traditional healers, so women being traditionally caretakers of the family's health may have impacted their knowledge on medicinal plants that exceed those of men. However, the predominance of women to men as the custodian of traditional 


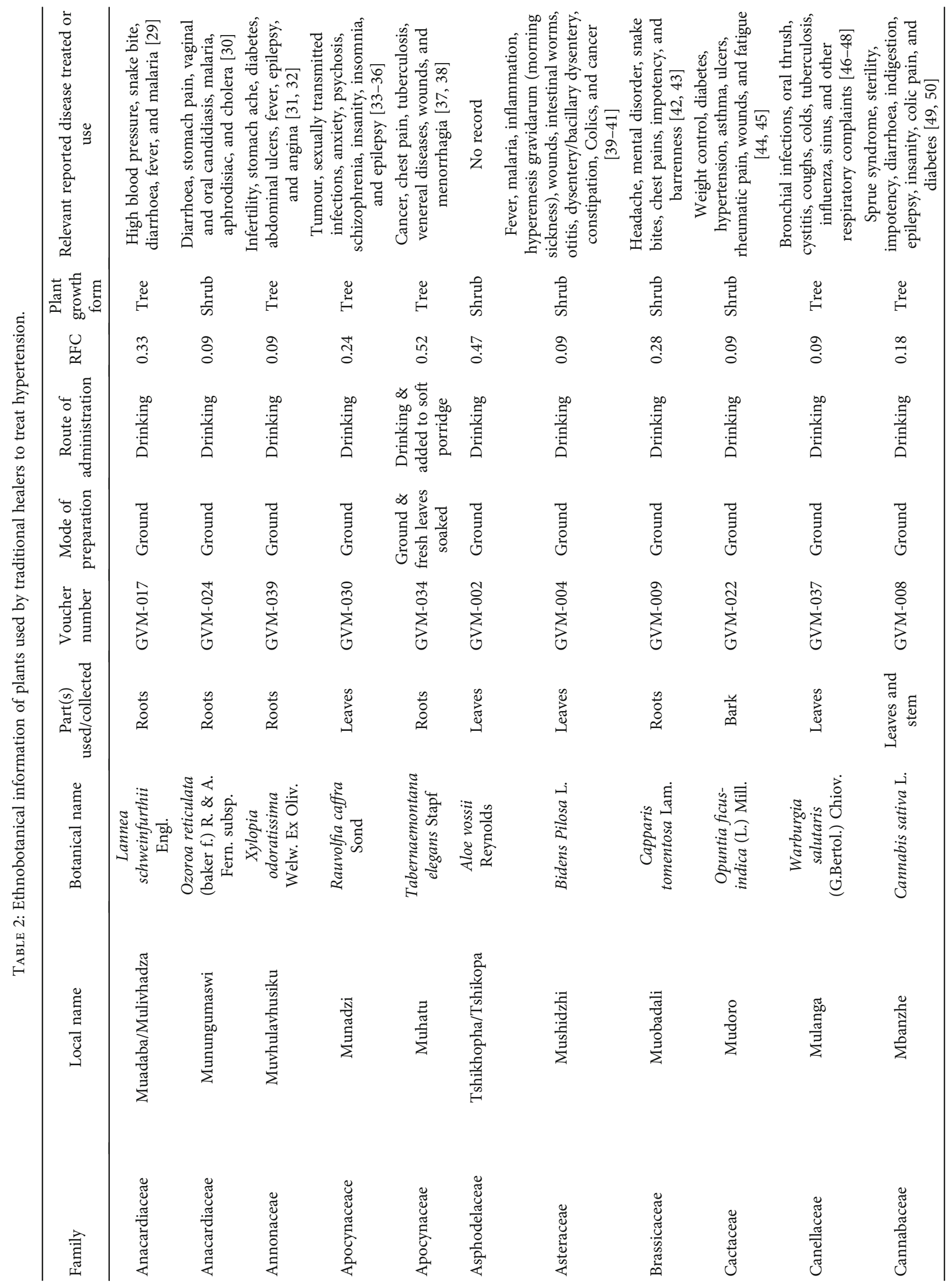




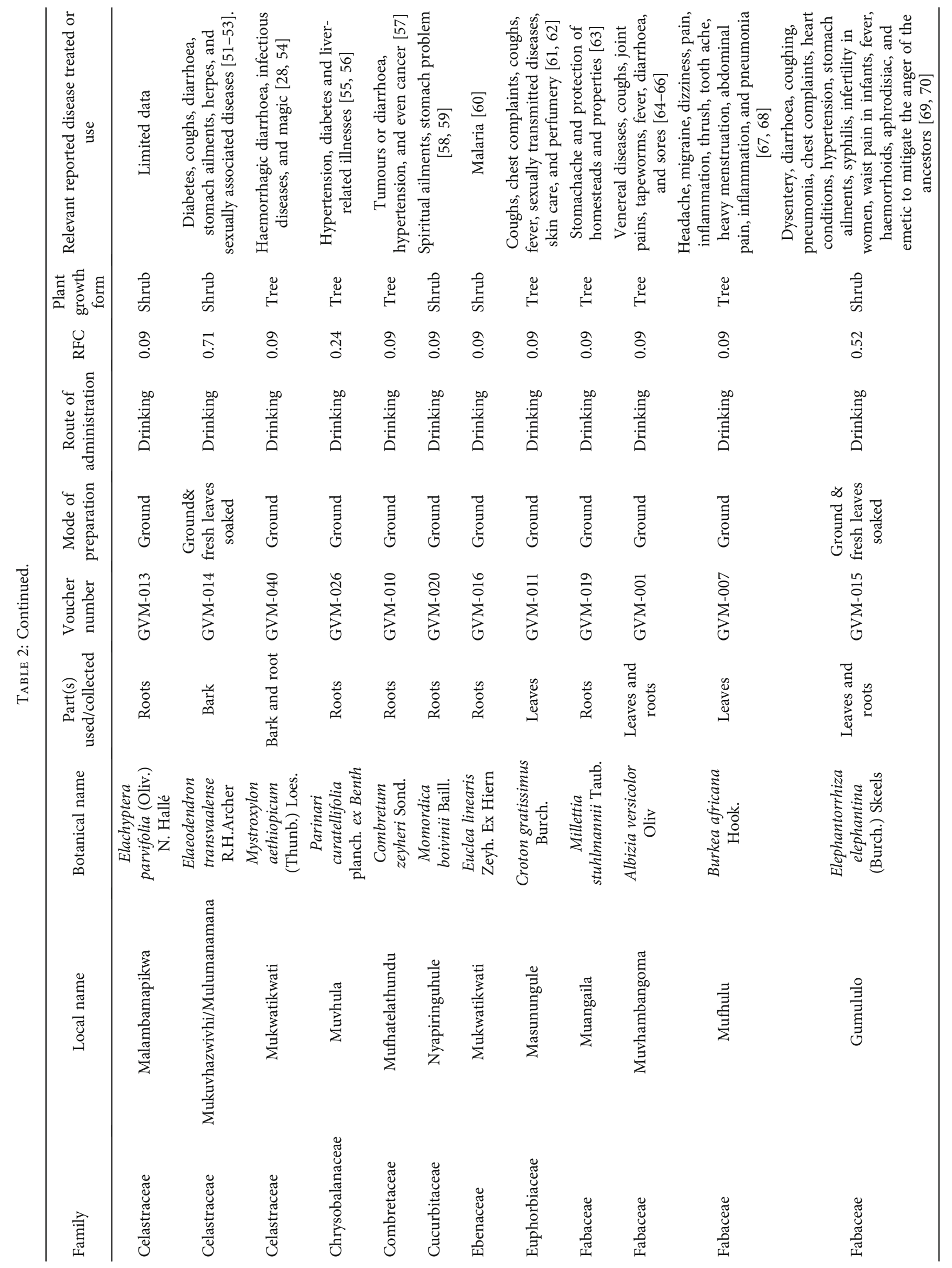




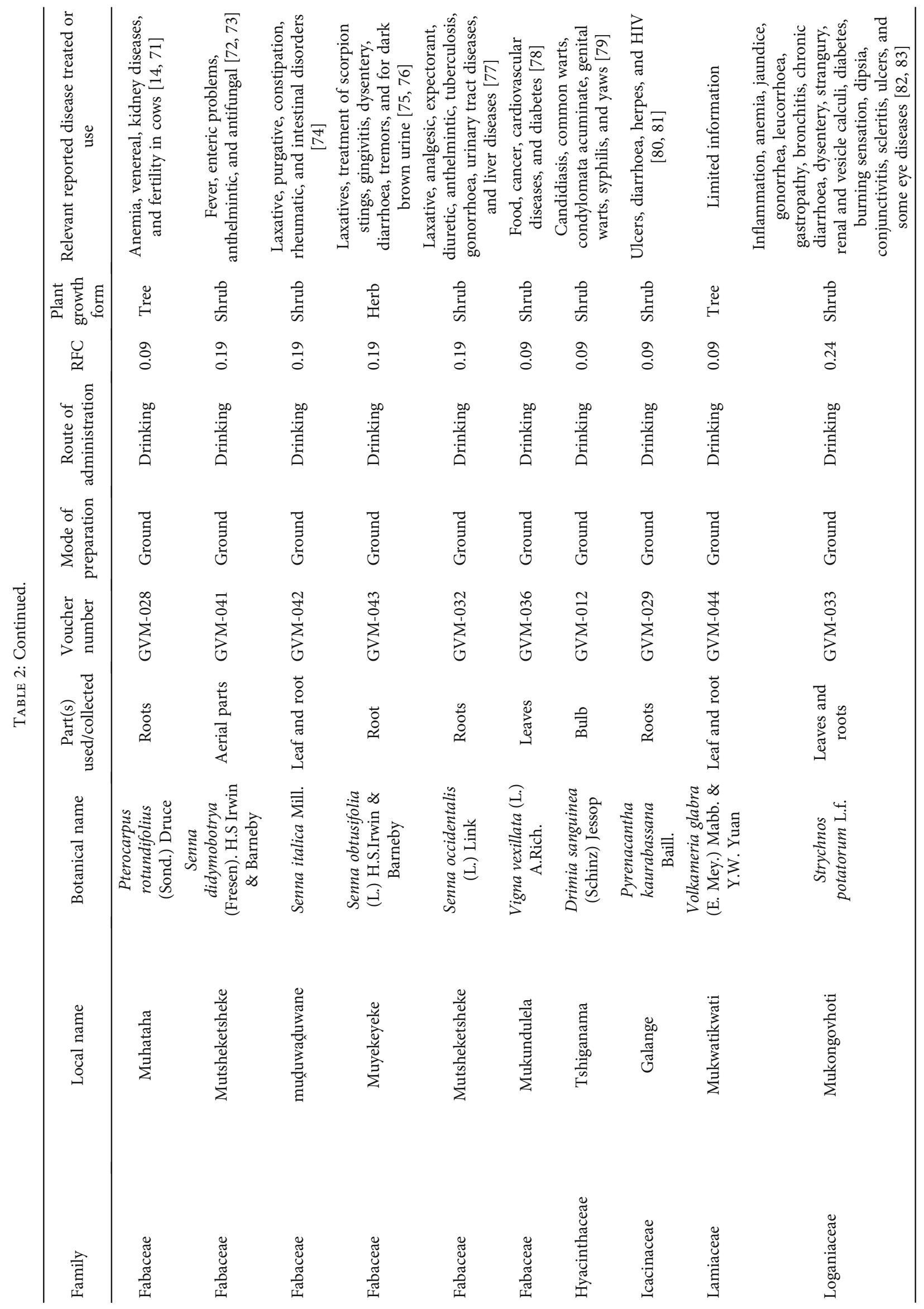




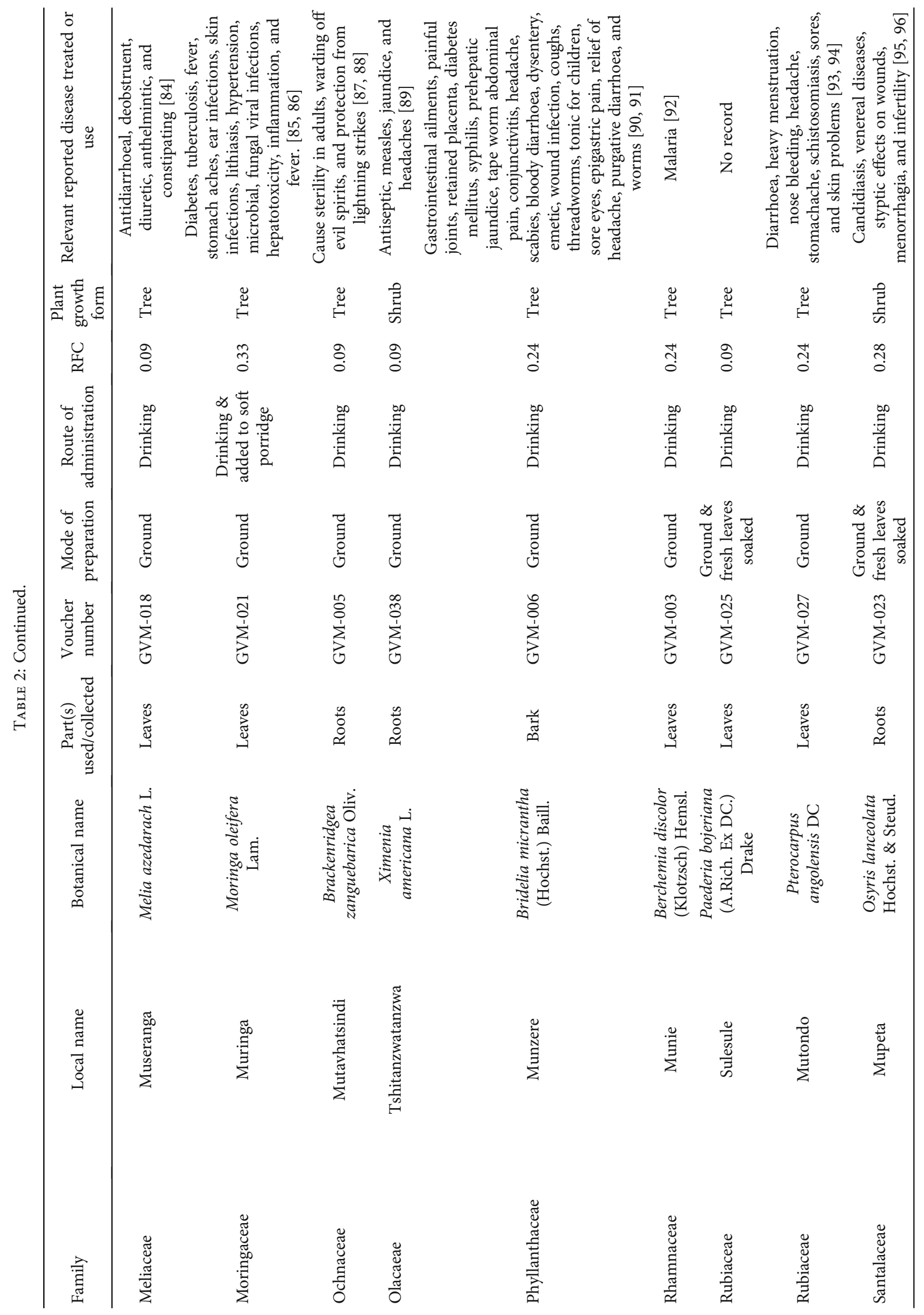




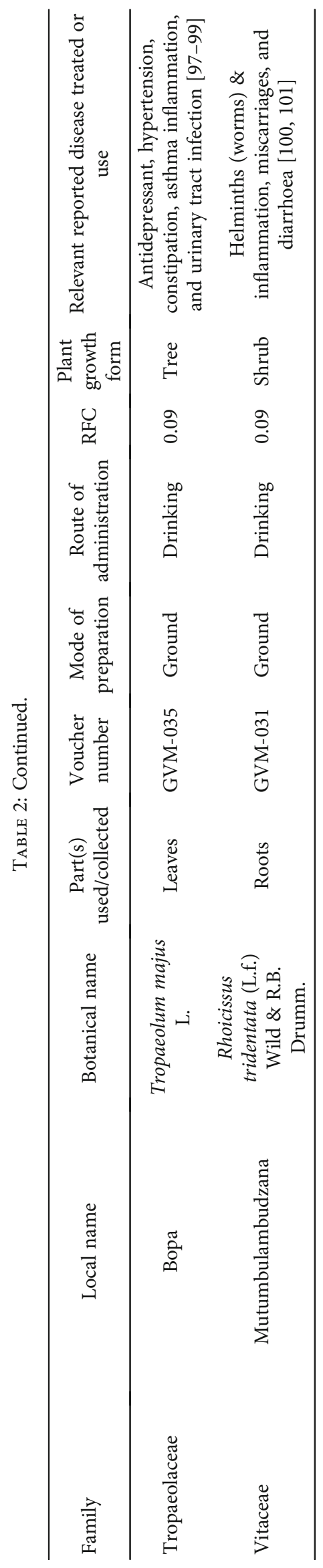




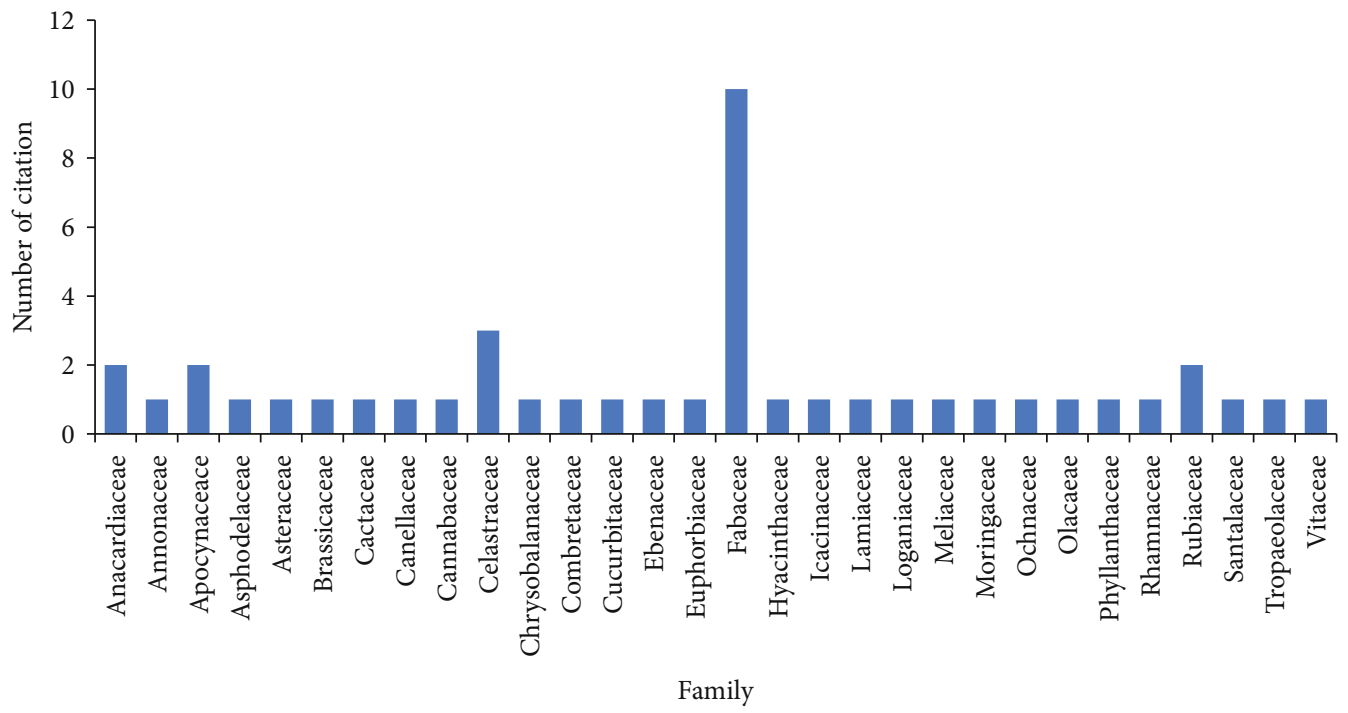

Figure 2: Distribution of use by traditional healers of plant families for the treatment of hypertension in the Vhembe district.

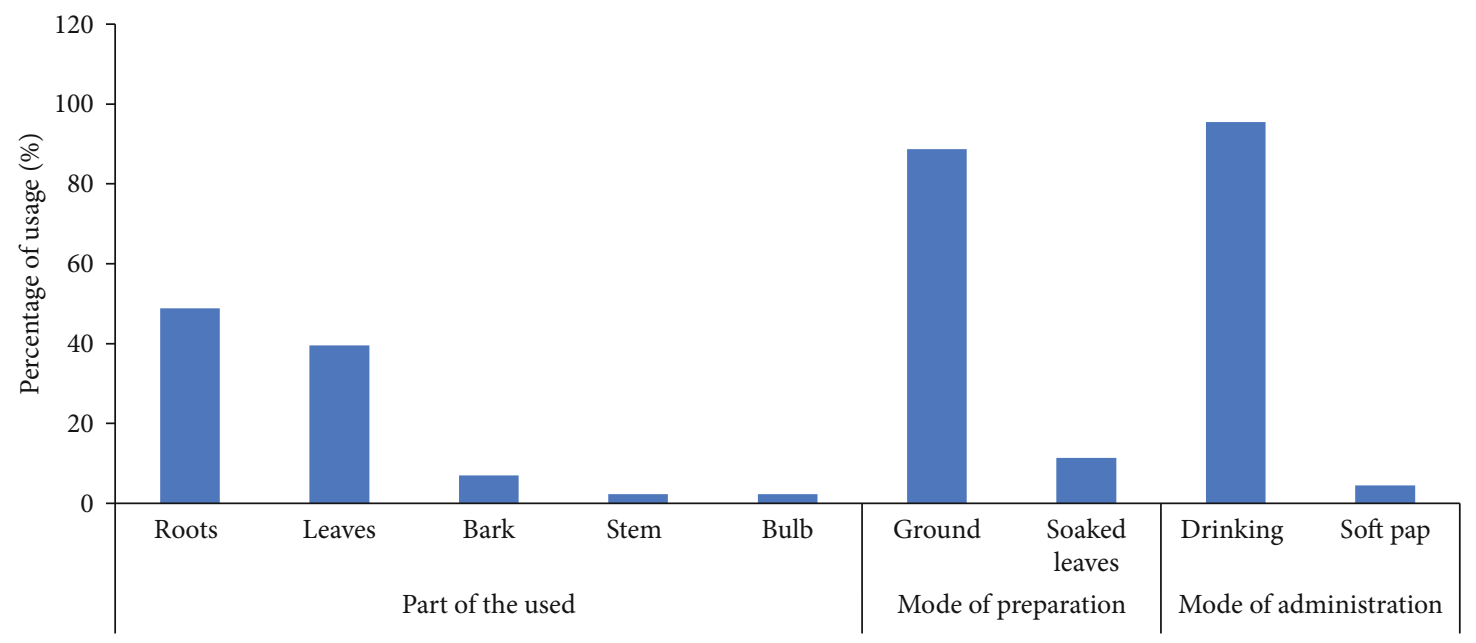

FIGURE 3: Plant parts as well as mode of preparation and administration of plants for use in treating hypertension.

knowledge varies according to the population under investigation in terms of their sociocultural characteristics. The higher percentage of ages between 55 and 66 years corroborates with previous reports suggesting that mainly adults and older people practice traditional medicine [103, 105, 106]. This study clearly shows the persistent gap in knowledge of herbal practice between the younger and older generations, suggesting the urgent need for documentation of this invaluable knowledge. Interestingly, the high education level of the informants and traditional healers in this study is enough to encourage the documentation of this knowledge or practice. This contrasts with reports that most traditional practitioners in Nigeria involved in maternal healthcare have no formal education [107].

4.2. Medicinal Plants Used in the Treatment of Hypertension. Most of the respondents in the present ethnobotanical survey mentioned medicinal plants belonging to the Fabaceae, Celastraceae, and Rubiaceae families. In other reports on the medicinal plants used for the treatment of hypertension, members of these families are often reported alongside with the Asteraceae and Rutaceae for use in the phytotherapy of various diseases including hypertension [50, 108-110]. In this study, the regular mention of the Fabaceae family is in agreement with previous reports on the plants used to manage hypertension [111-113]. This study also confirmed that the Fabaceae family is one of the plant families that is highly represented in the study area. The higher percentage usage of the roots and leaves is not uncommon and has been reported to be the preparation of herbal recipes in many other traditional medicines [114]. The reported findings in this study on the high frequency of leaves' use could be related to their visibility and ease of collection. The preparation of the leaves and roots in ground form for drinking is in agreement with surveys carried out in Ethiopia [115], Nigeria [116], Cameroon [117], and South Africa [108] suggesting that this is a common practice in traditional medicine. Most traditional healers may consider medicines that are milled in a mortar 
to a powder to be more efficient, as the powdered form of the plant material enhances the extraction of the active ingredients. Improved extraction efficiency from a powder may be due to a specific increase in the surface area of powdered particles that improves extraction of the medicinally important plant compounds. The predominance of trees to shrubs and herbs is similar to the survey in Botswana [118] and contrasts with the results of a survey in parts of the Eastern Cape province of South Africa where the commonly used plant is a herb [119]. To the best of our knowledge, Elaeodendron transvaalense and Tabernaemontana elegans frequently used in this study have never been reported in an ethnobotanical survey or investigated for the treatment of hypertension. However, Elephantorrhiza elephantina is part of the treatment regimen used by the Bapedi people for treating hypertension [120]. Elaeodendron transvaalense is also used in traditional medicine by the Vhavenda people of South Africa in the treatment of stomach ailments, cancer, diarrhoea, coughs, herpes, skin infections, inflammations, rashes, HIV/AIDS, and other sexually transmitted diseases. A report has indicated the extraction from E. transvaalense of three triterpenoids lup-20(30)-ene-3 $\alpha, 29$-diol, lup-20(29)-ene-30-hydroxy-3-one, and $\Psi$-taraxastanonol together with some polyphenols [52]. Extracts of the plant Tabernaemontana elegans are used as to wash wounds, treat heart and pulmonary diseases, chest pains, and cancer, and have been reported to contain monoterpene bisindole alkaloids, such as tabernaemontanine, dregamine, 16-epidregamine, tabernaelegantine $\mathrm{C}$, tabernaelegantinine $\mathrm{B}$, voacangine, and vobasine. In addition, the alkaloids from $T$. elegans have been reported to induce apoptosis in colon carcinoma cells and show antimicrobial activity $[38,121,122]$.

4.3. Antihypertensive Herbal Medicine Preparations and Route of Administration. This current study on plants used to treat hypertension reports mainly on single herbal preparations. Although there are reports on monocomponent recipes in traditional medicine, multiherbal preparations have also been reported [50, 108, 120]. Furthermore, the reported medicinal plants reported here are commonly used in the management of other disease conditions such as diabetes, cancer, sexually transmitted infections, tuberculosis, fever, skin infection, and sexual problems $[2,50,114,115,117$, $118,121,123]$. In this study, the preparation of the medicinal recipes was by decoction and administered orally.

4.4. Analysis of the Literature Data Compared with the Survey. A review of the literature for plants used to treat hypertension in South Africa identified a large number of medicinal species $(n=139)$, and some of these plants have also been reported elsewhere for the treatment of hypertension. In South Africa, the most frequently cited plants are Psidium guajava, Catharanthus roseus, Citrullus lanatus, Agave americana, Hypoxis hemerocallidea, Musa acuminata, Clausena anisata, Ruta graveolens, Lantana camara, Trichilia emetica, Leonotis leonurus, Ballota africana, Momordica charantia, and Cannabis sativa [124-129]. For instance, Psidium guajava with the highest citation is also commonly used in other parts of the world such as India, Mexico, Nige- ria, and Spain for the management of hypertension [124, 125, 129]. Comparison of the survey results with the literature data shows that the majority of the medicinal plants reported from the survey have not been previously reported for the treatment of hypertension. Although they appear in the inventory of plants used by the people of Vhenda, these plants have not been identified as antihypertensives [28]. This study indicates the multipurpose usage of medicinal plants and the dominance of the Fabaceae family of plants as an essential component of traditional medicine. With more than 490 species, the Fabaceae family is the second largest family of medicinal plants currently being used in traditional medicine. The family has been reported to show different medicinal potentials including antioxidant, antidiabetic, antibacterial, cytotoxic, and antihypertensive properties $[130,131]$. In parallel to the data reported in the current study, the possible mechanisms for the antihypertensive properties of the Fabaceae family may involve the PI3kinase/PKB/Akt pathway, inhibition of ACE and/or antioxidant properties [130].

4.4.1. Plant Species in the Survey Previously Investigated for Their Antihypertensive Properties. The antihypertensive activity of Opuntia ficus-indica Mill. was reported among Zulu medicinal plants where the aqueous leaf extract inhibited the activity of ACE in vitro [132]. Other investigations on O. ficus-indica have indicated antihypercholesterolemic, antihyperlipidemic, anti-inflammatory, and antioxidant activities perhaps due to the presence of phenolics and flavonoid compounds [133]. R. caffra, also known as quinine tree, is a fast-growing tree predominantly found in Africa. It is traditionally used for the treatment of hypertension, cough, stomach ailments, wounds, and diarrhoea [36]. Antihypertensive activity associated with this plant was shown by a reduction in the systolic and diastolic blood pressure in spontaneously hypertensive rats [134]. The high blood pressure lowering effect has been linked to the presence of reserpine [135]. The cultivation for food of Cannabis sativa L. also known as hemp has been limited due to the presence of the psychoactive compound (tetrahydrocannabinol). However, a peptide isolated from the hemp seed has been reported to show antioxidant and antihypertensive activities through the inhibition of ACE [136].

4.4.2. Toxicity Report. One of the traditional healers confirmed the warning that there is a need to carefully consider the use of Senna plant seeds in traditional remedies as the seeds of Senna occidentalis could be lethal [137]. The oral administration to rats of Elephantorrhiza elephantina extract was reported to lead to a decrease in their respiratory rate [123]. However, a report [52] confirmed that the use of Elaeodendron transvaalense showed few side effects. A report indicated that the extracts of $D$. sanguinea induced cardiac glycoside poisoning in sheep [138]. Foetidin, isolated from member of the Cucurbitaceae, has been reported to be toxic to certain cell lines [52]. Crude methanol and dichloromethane extracts of $S$. didymobotrya roots were reported to be toxic after a period of 14 days, killing $80 \%$ of mice at 
a dose of $5000 \mathrm{mg} / \mathrm{kg}$ body weight with an $\mathrm{LD}_{50}$ of $1927 \mathrm{mg} / \mathrm{kg}$ [103].

\section{Conclusion}

Traditional knowledge is sacred and is jealously guided. As a result, the Vhavenda people of South Africa have developed their own traditional way of treating hypertension. The present survey documented medicinal plants belonging to 30 families that are used for the treatment of hypertension and other diseases. Since the traditional healers in the study area use combinations of plants to treat hypertension, the efficacy of the treatment may be due to an ability to treat a broad spectrum of conditions such as bacterial infection, malaria, oxidative stress, and inflammation. This efficacy, together with the beneficial interaction between the healer and patient, may result in a psychosomatic improvement in the patient that combines to reduce blood pressure. However, according to the literature review, most of these plants have not been reported or investigated for their antihypertensive activity. This study will assist in the identification of useful plants. Also, these plants need to be investigated and their bioactive compounds isolated, to contribute to the discovery of new, effective, and affordable antihypertensive drugs.

\section{Data Availability}

All the data used to support the findings of this study are included within the articles, and the plant samples are available at the University of South Africa, Florida Campus.

\section{Conflicts of Interest}

The authors declare that they have no conflicts of interest.

\section{Supplementary Materials}

Supplementary Table 1: ethnopharmacological details of reported medicinal plants used by traditional healers in South Africa. (Supplementary Materials)

\section{References}

[1] D. Davids, D. Gibson, and Q. Johnson, "Ethnobotanical survey of medicinal plants used to manage high blood pressure and type 2 diabetes mellitus in Bitterfontein, Western Cape Province, South Africa," Journal of Ethnopharmacology, vol. 194, pp. 755-766, 2016.

[2] K. Malik, M. Ahmad, R. W. Bussmann et al., "Ethnobotany of anti-hypertensive plants used in northern Pakistan," Frontiers in Pharmacology, vol. 9, p. 789, 2018.

[3] M. Eddouks, M. Maghrani, A. Lemhadri, M.-L. Ouahidi, and H. Jouad, "Ethnopharmacological survey of medicinal plants used for the treatment of diabetes mellitus, hypertension and cardiac diseases in the south-east region of Morocco (Tafilalet).," Journal of Ethnopharmacology, vol. 82, no. 2-3, pp. 97-103, 2002.

[4] S. R. Tee, X. Y. Teoh, W. A. Aiman, A. Aiful, C. S. Har, and Z. F. Tan, "The prevalence of hypertension and its associated risk factors in two rural communities in Penang, Malaysia,"
International e-Journal of Medical Science and Education, vol. 4, no. 2, pp. 27-40, 2010.

[5] M. E. Hall, J. M. do Carmo, A. A. da Silva, L. A. Juncos, Z. Wang, and J. E. Hall, "Obesity, hypertension, and chronic kidney disease," International Journal of Nephrology and Renovascular Disease, vol. 7, pp. 75-88, 2014.

[6] J. R. Petrie, T. J. Guzik, and R. M. Touyz, "Diabetes, hypertension, and cardiovascular disease: clinical insights and vascular mechanisms," The Canadian Journal of Cardiology, vol. 34, no. 5, pp. 575-584, 2018.

[7] D. Van Rooyen, B. Pretorius, N. M. Tembani, and W. ten Ham, Curationis, vol. 38, no. 2, 2015DENOSA, 2015.

[8] O. Oyebode, N. Kandala, P. J. Chilton, and R. J. Lilford, "Use of traditional medicine in middle-income countries: a WHOSAGE study," Health Policy and Planning, vol. 31, no. 8, pp. 984-991, 2016.

[9] M. Ashu Agbor and S. Naidoo, "Ethnomedicinal plants used by traditional healers to treat oral health problems in Cameroon," Evidence-Based Complementary and Alternative Medicine, vol. 2015, Article ID 649832, 10 pages, 2015.

[10] A. M. Agbor and S. Naidoo, "A review of the role of African traditional medicine in the management of oral diseases," African Journal of Traditional, Complementary and Alternative Medicines, vol. 13, no. 2, pp. 133-142, 2016.

[11] B. Güler, E. Manav, and E. Uğurlu, "Medicinal plants used by traditional healers in Bozüyük (Bilecik-Turkey)," Journal of Ethnopharmacology, vol. 173, pp. 39-47, 2015.

[12] V. Nanadagopalan, M. J. Gritto, and A. Doss, "An ethnobotanical survey of medicinal plants used by local traditional healers of Thiruvengimalai, Tiruchirapalli district, Tamil Nadu, southern India," Asian Journal of Pharmaceutical Science \& Technology, vol. 5, no. 3, pp. 156-159, 2015.

[13] M. G. Hewson, "Integrating indigenous knowledge with science teaching," in Embracing Indigenous Knowledge in Science and Medical Teaching, pp. 119-131, Springer, 2015.

[14] T. E. Tshikalange, B. C. Mophuting, J. Mahore, S. Winterboer, and N. Lall, "An ethnobotanical study of medicinal plants used in villages under Jongilanga Tribal Council, Mpumalanga, South Africa," African Journal of Traditional, Complementary and Alternative Medicines, vol. 13, no. 6, pp. 83-89, 2016.

[15] C. C. Asuzu, T. Elumelu-Kupoluyi, M. C. Asuzu, O. B. Campbell, E. O. Akin-Odanye, and D. Lounsbury, "A pilot study of cancer patients' use of traditional healers in the Radiotherapy Department, University College Hospital, Ibadan, Nigeria," Psycho-Oncology, vol. 26, no. 3, pp. 369-376, 2017.

[16] C. M. Audet, J. Salato, M. Blevins et al., "Occupational hazards of traditional healers: repeated unprotected blood exposures risk infectious disease transmission," Tropical Medicine \& International Health, vol. 21, no. 11, pp. 1476-1480, 2016.

[17] K. C. Chinsembu, "Ethnobotanical study of medicinal flora utilised by traditional healers in the management of sexually transmitted infections in Sesheke District, Western Province, Zambia," Revista Brasileira de Farmacognosia, vol. 26, no. 2, pp. 268-274, 2016.

[18] K. Maneenoon, C. Khuniad, Y. Teanuan et al., "Ethnomedicinal plants used by traditional healers in Phatthalung Province, Peninsular Thailand," Journal of Ethnobiology and Ethnomedicine, vol. 11, no. 1, p. 43, 2015.

[19] T. Ngarivhume, C. I. E. A. van't Klooster, J. T. V. M. de Jong, and J. H. Van der Westhuizen, "Medicinal plants used by 
traditional healers for the treatment of malaria in the Chipinge district in Zimbabwe," Journal of Ethnopharmacology, vol. 159, pp. 224-237, 2015.

[20] C. W. Musyimi, V. N. Mutiso, E. S. Nandoya, and D. M. Ndetei, "Forming a joint dialogue among faith healers, traditional healers and formal health workers in mental health in a Kenyan setting: towards common grounds," Journal of Ethnobiology and Ethnomedicine, vol. 12, no. 1, p. 4, 2016.

[21] O. Esan, J. Appiah-Poku, C. Othieno et al., "A survey of traditional and faith healers providing mental health care in three sub-Saharan African countries," Social Psychiatry and Psychiatric Epidemiology, vol. 54, no. 3, pp. 395-403, 2019.

[22] Government Gazette No 30660, Traditional Health Practitioners Act 22 of 2007, Department of Health, Government Printing Works, 2008.

[23] G. Louw and A. Duvenhage, "Are there 200,000 and more traditional healers practicing in South Africa?," Australasian Medical Journal, vol. 9, no. 12, pp. 498-505, 2016.

[24] B. Tshehla, "Traditional health practitioners and the authority to issue medical certificates," South African Medical Journal, vol. 105, no. 4, p. 279, 2015.

[25] S. A. Motadi, X. G. Mbhenyane, H. V. Mbhatsani, N. S. Mabapa, and R. L. Mamabolo, "Prevalence of iron and zinc deficiencies among preschool children ages 3 to $5 \mathrm{y}$ in Vhembe district, Limpopo province, South Africa," Nutrition, vol. 31, no. 3, pp. 452-458, 2015.

[26] Municipalities of South Africa, "Vhembe District Municipality (DC34)," Municipalities of South Africa, 2017, 2019, https://municipalities.co.za/services/129/vhembe-districtmunicipality.

[27] Statistics South Africa, "Local Municipality | Statistics South Africa," 2011, 2019, http://www.statssa.gov.za/?page_id= 993\&id=thulamela-municipality.

[28] K. Magwede, B.-E. van Wyk, and A. E. van Wyk, "An inventory of Vhavenda useful plants," South African Journal of Botany, vol. 122, pp. 57-89, 2019.

[29] A. Maroyi, "Review of ethnomedicinal, phytochemical and pharmacological properties of Lannea schweinfurthii (Engl.) Engl.," Molecules, vol. 24, no. 4, p. 732, 2019.

[30] S. M. Maregesi, O. D. Ngassapa, L. Pieters, and A. J. Vlietinck, "Ethnopharmacological survey of the Bunda district, Tanzania: plants used to treat infectious diseases," Journal of Ethnopharmacology, vol. 113, no. 3, pp. 457-470, 2007.

[31] N. A. F. Fernandes, L. I. N. Canelo, D. I. M. D. de Mendonça, and A. J. G. de Mendonça, "Acetylcholinesterase inhibitory activity of extracts from Angolan medicinal plants," International Journal of Pharmacognosy and Phytochemical Research, vol. 7, no. 4, pp. 768-776, 2015.

[32] S. Suzana Augustino, J. B. Hall, F. B. S. Makonda, and R. C. Ishengoma, "Medicinal resources of the Miombo woodlands of Urumwa, Tanzania: plants and its uses," Journal of Medicinal Plants Research, vol. 5, no. 27, pp. 6352-6372, 2011.

[33] A. M. A. G. Nasser and W. E. Court, "Stem bark alkaloids of rauvolfia caffra," Journal of Ethnopharmacology, vol. 11, no. 1, pp. 99-117, 1984.

[34] S. Bindu, K. B. Rameshkumar, B. Kumar, A. Singh, and C. Anilkumar, "Distribution of reserpine in Rauvolfia species from India - HPTLC and LC-MS studies," Industrial Crops and Products, vol. 62, pp. 430-436, 2014.

[35] T. E. Tshikalange, J. J. M. Meyer, and A. A. Hussein, "Antimicrobial activity, toxicity and the isolation of a bioactive com- pound from plants used to treat sexually transmitted diseases," Journal of Ethnopharmacology, vol. 96, no. 3, pp. 515-519, 2005.

[36] T. K. Milugo, L. K. Omosa, J. O. Ochanda et al., "Antagonistic effect of alkaloids and saponins on bioactivity in the quinine tree (Rauvolfia caffra sond.): further evidence to support biotechnology in traditional medicinal plants," BMC Complementary and Alternative Medicine, vol. 13, no. 1, p. 285, 2013.

[37] C. Pallant and V. Steenkamp, "In-vitro bioactivity of Venda medicinal plants used in the treatment of respiratory conditions," Human \& Experimental Toxicology, vol. 27, no. 11, pp. 859-866, 2008.

[38] T. A. Mansoor, P. M. Borralho, S. Dewanjee, S. Mulhovo, C. M. P. Rodrigues, and M. J. U. Ferreira, "Monoterpene bisindole alkaloids, from the African medicinal plant Tabernaemontana elegans, induce apoptosis in HCT116 human colon carcinoma cells," Journal of Ethnopharmacology, vol. 149, no. 2, pp. 463-470, 2013.

[39] A. P. Bartolome, I. M. Villaseñor, and W.-C. Yang, "Bidens pilosa L. (Asteraceae): botanical properties, traditional uses, phytochemistry, and pharmacology," Evidence-Based Complementary and Alternative Medicine, vol. 2013, Article ID 340215, 51 pages, 2013.

[40] T. V. N. Thien, V. H. T. Huynh, L. K. T. Vo et al., "Two new compounds and $\alpha$-glucosidase inhibitors from the leaves of Bidens pilosa L.," Phytochemistry Letters, vol. 20, pp. 119122, 2017.

[41] F. Oliveira, V. Andrade-Neto, A. Krettli, and M. G. Brandão, "New evidences of antimalarial activity of Bidens pilosa roots extract correlated with polyacetylene and flavonoids," Journal of Ethnopharmacology, vol. 93, no. 1, pp. 39-42, 2004.

[42] O. Akoto, I. V. Oppong, I. Addae-Mensah, R. Waibel, and $\mathrm{H}$. Achenbach, "Isolation and characterization of dipeptide derivative and phytosterol from Capparis tomentosa Lam," Scientific Research and Essay, vol. 3, no. 8, pp. 355-358, 2008.

[43] G. H. Tekulu, T. Hiluf, H. Brhanu, E. M. Araya, H. Bitew, and T. Haile, "Anti-inflammatory and anti-nociceptive property of Capparis tomentosa Lam. root extracts," Journal of Ethnopharmacology, vol. 253, p. 112654, 2020.

[44] E. Salehi, Z. Emam-Djomeh, G. Askari, and M. Fathi, “Opuntia ficus indica fruit gum: extraction, characterization, antioxidant activity and functional properties," Carbohydrate Polymers, vol. 206, pp. 565-572, 2019.

[45] U. Osuna-Martínez, J. Reyes-Esparza, and L. Rodríguez-Fragoso, "Cactus (Opuntia ficus-indica): a review on its antioxidants properties and potential pharmacological use in chronic diseases," Natural Products Chemistry \& Research, vol. 2, no. 6, 2014.

[46] G. P. Khumalo, N. J. Sadgrove, S. Van Vuuren, and B.-E. Van Wyk, "Antimicrobial activity of volatile and non-volatile isolated compounds and extracts from the bark and leaves of Warburgia salutaris (Canellaceae) against skin and respiratory pathogens," South African Journal of Botany, vol. 122, pp. 547-550, 2019.

[47] E. L. Kotina, B.-E. Van Wyk, and P. M. Tilney, "Anatomy of the leaf and bark of Warburgia salutaris (Canellaceae), an important medicinal plant from South Africa," South African Journal of Botany, vol. 94, pp. 177-181, 2014.

[48] T. Rabe and J. van Staden, "Isolation of an antibacterial sesquiterpenoid from Warburgia salutaris," Journal of Ethnopharmacology, vol. 73, no. 1-2, pp. 171-174, 2000. 
[49] E. B. Russo, "Cannabis and epilepsy: an ancient treatment returns to the fore," Epilepsy \& Behavior, vol. 70, Part B, pp. 292-297, 2017.

[50] S. Odeyemi and G. Bradley, "Medicinal plants used for the traditional management of diabetes in the Eastern Cape, South Africa: pharmacology and toxicology," Molecules, vol. 23, 2018.

[51] M. S. S. Deutschländer, M. van de Venter, S. Roux, J. Louw, and N. Lall, "Hypoglycaemic activity of four plant extracts traditionally used in South Africa for diabetes," Journal of Ethnopharmacology, vol. 124, no. 3, pp. 619-624, 2009.

[52] T. E. Tshikalange and A. Hussein, "Cytotoxicity activity of isolated compounds from Elaeodendron transvaalense ethanol extract," Journal of Medicinal Plants Research, vol. 4, no. 16, pp. 1695-1697, 2010.

[53] G. P. Khumalo, N. J. Sadgrove, S. F. Van Vuuren, and B.E. Van Wyk, "Antimicrobial lupenol triterpenes and a polyphenol from Elaeodendron transvaalense, a popular southern African medicinal bark," South African Journal of Botany, vol. 122, pp. 518-521, 2019.

[54] H. J. de Boer, A. Kool, A. Broberg, W. R. Mziray, I. Hedberg, and J. J. Levenfors, "Anti-fungal and anti-bacterial activity of some herbal remedies from Tanzania," Journal of Ethnopharmacology, vol. 96, no. 3, pp. 461-469, 2005.

[55] M. T. Olaleye, A. E. Amobonye, K. Komolafe, and A. C. Akinmoladun, "Protective effects of Parinari curatellifolia flavonoids against acetaminophen-induced hepatic necrosis in rats," Saudi Journal of Biological Sciences, vol. 21, no. 5, pp. 486-492, 2014.

[56] S. Ogbonnia, "Extracts of Mobola plum (Parinari curatellifolia Planch ex Benth, Chrysobalanaceae) seeds and multiple therapeutic activities," in Nuts and Seeds in Health and Disease Prevention, pp. 767-774, Academic Press, 2011.

[57] P. Fyhrquist, L. Mwasumbi, C.-A. Hæggström, H. Vuorela, R. Hiltunen, and P. Vuorela, "Ethnobotanical and antimicrobial investigation on some species of Terminalia and Combretum (Combretaceae) growing in Tanzania," Journal of Ethnopharmacology, vol. 79, no. 2, pp. 169-177, 2002.

[58] F. Tamiru, L. Adane, and B. Bekele, "Phytochemical screening of root extract of Momordica boivinii and isolation of two steroids," Research Journal of Phytochemistry, vol. 12, no. 1, pp. 21-34, 2018.

[59] M. Pakia, J. A. Cooke, and J. van Staden, "The ethnobotany of the Midzichenda tribes of the coastal forest areas in Kenya: 2. Medicinal plant uses," South African Journal of Botany, vol. 69, no. 3, pp. 382-395, 2003.

[60] K. C. Chinsembu, "Plants as antimalarial agents in subSaharan Africa," Acta Tropica, vol. 152, pp. 32-48, 2015.

[61] S. F. van Vuuren and A. M. Viljoen, "In vitro evidence of phyto-synergy for plant part combinations of Croton gratissimus (Euphorbiaceae) used in African traditional healing," Journal of Ethnopharmacology, vol. 119, no. 3, pp. 700-704, 2008.

[62] N. J. Sadgrove, L. G. Madeley, and B.-E. Van Wyk, "Volatiles from African species of Croton (Euphorbiaceae), including new diterpenes in essential oil from Croton gratissimus," Heliyon, vol. 5, no. 10, article e02677, 2019.

[63] M. Tshisikhawe, N. M. Siaga, and R. B. Bhat, "Population dynamics of Millettia stuhlmannii Taub. in Ha-Makhuvha, Vhembe district of Limpopo Province, South Africa," Phyton, vol. 80, pp. 127-132, 2011.
[64] K. C. Chinsembu, A. Hijarunguru, and A. Mbangu, "Ethnomedicinal plants used by traditional healers in the management of HIV/AIDS opportunistic diseases in Rundu, Kavango East Region, Namibia," South African Journal of Botany, vol. 100, pp. 33-42, 2015.

[65] N. C. Dlova and M. A. Ollengo, "Traditional and ethnobotanical dermatology practices in Africa," Clinics in Dermatology, vol. 36, no. 3, pp. 353-362, 2018.

[66] G. M. Rukunga and P. G. Waterman, "Triterpenes of Albizia versicolor and Albizia schimperana stem barks," Fitoterapia, vol. 72, no. 2, pp. 188-190, 2001.

[67] J. P. Dzoyem and J. N. Eloff, "Anti-inflammatory, anticholinesterase and antioxidant activity of leaf extracts of twelve plants used traditionally to alleviate pain and inflammation in South Africa," Journal of Ethnopharmacology, vol. 160, pp. 194-201, 2015.

[68] E. Mathisen, D. Diallo, Ø. M. Andersen, and K. E. Malterud, "Antioxidants from the bark ofBurkea africana, an African medicinal plant," Phytotherapy Research, vol. 16, no. 2, pp. 148-153, 2002.

[69] O. O. Olaokun, A. E. Alaba, K. Ligege, and N. M. Mkolo, "Phytochemical content, antidiabetes, anti-inflammatory antioxidant and cytotoxic activity of leaf extracts of Elephantorrhiza elephantina (Burch.) Skeels," South African Journal of Botany, vol. 128, pp. 319-325, 2020.

[70] V. Maphosa, P. Masika, and B. Moyo, "Investigation of the anti-inflammatory and antinociceptive activities of Elephantorrhiza elephantina (Burch.) Skeels root extract in male rats," African Journal of Biotechnology, vol. 8, no. 24, 2009.

[71] N. Lall, A. Blom van Staden, S. Rademan et al., "Antityrosinase and anti-acne potential of plants traditionally used in the Jongilanga community in Mpumalanga," South African Journal of Botany, vol. 126, pp. 241-249, 2019.

[72] T. Anthoney Swamy, M. C. Ngule, K. Jackie, A. Edwin, and M. E. Ngule, "Evaluation of in vitro antibacterial activity in Senna didymobotrya roots methanolic-aqua extract and the selected fractions against selected pathogenic microorganisms," International Journal of Current Microbiology and Applied Sciences, vol. 3, no. 5, pp. 362-376, 2014.

[73] J. K. Mworia, C. M. Kibiti, M. P. Ngugi, and J. N. Ngeranwa, "Antipyretic potential of dichloromethane leaf extract of Eucalyptus globulus (Labill) and Senna didymobotrya (Fresenius) in rats models," Heliyon, vol. 5, no. 12, article e02924, 2019.

[74] Y. Dabai, A. Kawo, and R. M. Aliyu, "Phytochemical screening and antibacterial activity of the leaf and root extracts of Senna italica," African Journal of Pharmacy and Pharmacology, vol. 6, no. 12, 2012.

[75] I. Y. Sudi, D. M. Ksgbiya, E. K. Muluh, and A. Clement, "Nutritional and phytochemical screening of Senna obtusifolia indigenous to Mubi, Nigeria," Advances in Applied Science Research, vol. 2, no. 3, pp. 432-437, 2011.

[76] J. H. Doughari, A. M. El-Mahmood, and I. Tyoyina, "Antimicrobial activity of leaf extracts of Senna obtusifolia (L)," African Journal of Pharmacy and Pharmacology, vol. 2, no. 1, pp. 7-13, 2008.

[77] A. V. F. F. Teles, R. A. Fock, and S. L. Górniak, "Effects of longterm administration of Senna occidentalis seeds on the hematopoietic tissue of rats," Toxicon, vol. 108, pp. 73-79, 2015.

[78] K. Sowndhararajan, P. Siddhuraju, and S. Manian, "Antioxidant and free radical scavenging capacity of the underutilized 
legume, Vigna vexillata (L.) A. Rich," Journal of Food Composition and Analysis, vol. 24, no. 2, pp. 160-165, 2011.

[79] J. A. Asong, P. T. Ndhlovu, N. S. Khosana, A. O. Aremu, and W. Otang-Mbeng, "Medicinal plants used for skin-related diseases among the Batswanas in Ngaka Modiri Molema District Municipality, South Africa," South African Journal of Botany, vol. 126, pp. 11-20, 2019.

[80] L. Boudesocque-Delaye, D. Agostinho, C. Bodet et al., "Antibacterial polyketide heterodimers from Pyrenacantha kaurabassana tubers," Journal of Natural Products, vol. 78, no. 4, pp. 597-603, 2015.

[81] J. J. Omolo, V. Maharaj, D. Naidoo et al., "Bioassay-guided investigation of the Tanzanian plant Pyrenacantha kaurabassana for potential anti-HIV-active compounds," Journal of Natural Products, vol. 75, no. 10, pp. 1712-1716, 2012.

[82] P. B. Mallikharjuna, L. N. Rajanna, Y. N. Seetharam, and G. K. Sharanabasappa, "Phytochemical studies of Strychnos potatorum L.f.- a medicinal plant," E-Journal of Chemistry, vol. 4, no. 4, pp. 510-518, 2007.

[83] E. Sanmugapriya and S. Venkataraman, "Studies on hepatoprotective and antioxidant actions of Strychnos potatorum Linn. seeds on CCl4-induced acute hepatic injury in experimental rats," Journal of Ethnopharmacology, vol. 105, no. 12, pp. 154-160, 2006.

[84] D. Sharma and Y. P. S. Dr, "Preliminary and pharmacological profile of Melia azedarach L.: an overview," Journal of Applied Pharmaceutical Science, vol. 3, no. 12, pp. 133-138, 2013.

[85] S. Suresh, A. S. Chhipa, M. Gupta et al., "Phytochemical analysis and pharmacological evaluation of methanolic leaf extract of Moringa oleifera Lam. in ovalbumin induced allergic asthma," South African Journal of Botany, vol. 130, pp. 484-493, 2020.

[86] I. Ngom, B. D. Ngom, J. Sackey, and S. Khamlich, "Biosynthesis of Zinc Oxide Nanoparticles Using Extracts of Moringa Oleifera: Structural \& Optical Properties," Materials Today: Proceedings, 2020.

[87] S. E. Drewes and N. A. Hudson, "Brackenin, a dimeric dihydrochalcone from Brackenridgea zanguebarica," Phytochemistry, vol. 22, no. 12, pp. 2823-2825, 1983.

[88] S. E. Drewes, N. A. Hudson, R. B. Bates, and G. S. Linz, "Medicinal plants of Southern Africa. Part 1. Dimeric chalcone-based pigments from Brackenridgea zanguebarica," Journal of the Chemical Society, Perkin Transactions 1, pp. 2809-2813, 1987.

[89] G. F. Sousa Carvalho, L. K. Marques, H. G. Sousa et al., "Phytochemical study, molecular docking, genotoxicity and therapeutic efficacy of the aqueous extract of the stem bark of Ximenia americana L. in the treatment of experimental COPD in rats," Journal of Ethnopharmacology, vol. 247, p. 112259, 2020.

[90] T. A. Ngueyem, G. Brusotti, G. Caccialanza, and P. V. Finzi, "The genus Bridelia: a phytochemical and ethnopharmacological review," Journal of Ethnopharmacology, vol. 124, no. 3, pp. 339-349, 2009.

[91] E. Green, L. C. Obi, A. Samie, P. O. Bessong, and R. N. Ndip, "Characterization of n-Hexane sub-fraction of Bridelia micrantha (Berth) and its antimycobacterium activity," BMC Complementary and Alternative Medicine, vol. 11, no. 1, p. 28, 2011.

[92] Y.-W. Chin, L. K. Mdee, Z. H. Mbwambo et al., "Prenylated flavonoids from the root bark of Berchemia discolor, a Tanza- nian medicinal plant," Journal of Natural Products, vol. 69, no. 11, pp. 1649-1652, 2006.

[93] A. Samie, A. Housein, N. Lall, and J. J. M. Meyer, "Crude extracts of, and purified compounds from, Pterocarpus angolensis, and the essential oil of Lippia javanica: their in-vitro cytotoxicities and activities against selected bacteria and Entamoeba histolytica," Annals of Tropical Medicine and Parasitology, vol. 103, no. 5, pp. 427-439, 2013.

[94] A. Maroyi, "Traditional use of medicinal plants in southcentral Zimbabwe: review and perspectives," Journal of Ethnobiology and Ethnomedicine, vol. 9, no. 1, p. 31, 2013.

[95] R. B. Mulaudzi, A. R. Ndhlala, M. G. Kulkarni, J. F. Finnie, and J. Van Staden, "Antimicrobial properties and phenolic contents of medicinal plants used by the Venda people for conditions related to venereal diseases," Journal of Ethnopharmacology, vol. 135, no. 2, pp. 330-337, 2011.

[96] N. A. Masevhe, L. J. McGaw, and J. N. Eloff, “The traditional use of plants to manage candidiasis and related infections in Venda, South Africa," Journal of Ethnopharmacology, vol. 168, pp. 364-372, 2015.

[97] A. C. Melo, S. C. A. Costa, A. F. Castro et al., "Hydroethanolic extract of Tropaeolum majus promotes anxiolytic effects on rats," Revista Brasileira de Farmacognosia, vol. 28, no. 5, pp. 589-593, 2018.

[98] C. Gomes, E. L. B. Lourenço, É. B. Liuti et al., "Evaluation of subchronic toxicity of the hydroethanolic extract of Tropaeolum majus in Wistar rats," Journal of Ethnopharmacology, vol. 142, no. 2, pp. 481-487, 2012.

[99] S. Valsalam, P. Agastian, M. V. Arasu et al., "Rapid biosynthesis and characterization of silver nanoparticles from the leaf extract of Tropaeolum majus L. and its enhanced invitro antibacterial, antifungal, antioxidant and anticancer properties," Journal of Photochemistry and Photobiology B: Biology, vol. 191, pp. 65-74, 2019.

[100] E. Green, A. Samie, C. L. Obi, P. O. Bessong, and R. N. Ndip, "Inhibitory properties of selected South African medicinal plants against Mycobacterium tuberculosis," Journal of Ethnopharmacology, vol. 130, no. 1, pp. 151-157, 2010.

[101] F. O. Orech and J. G. Schwarz, "Ethno-phytotherapeutic remedies used in meat, milk, and blood products by the Maasai people of Kenya," South African Journal of Botany, vol. 108, pp. 278-280, 2017.

[102] V. Urso, M. A. Signorini, M. Tonini, and P. Bruschi, "Wild medicinal and food plants used by communities living in Mopane woodlands of southern Angola: results of an ethnobotanical field investigation," Journal of Ethnopharmacology, vol. 177, pp. 126-139, 2016.

[103] R. Korir, C. Mutai, C. Kiiyukia, and C. Bii, "Antimicrobial activity and safety of two medicinal plants traditionally used in Bomet District of Kenya," Research Journal of Medicinal Plant, vol. 6, no. 5, pp. 370-382, 2012.

[104] S. Suleman, T. Beyene Tufa, D. Kebebe et al., “Treatment of malaria and related symptoms using traditional herbal medicine in Ethiopia," Journal of Ethnopharmacology, vol. 213, pp. 262-279, 2018.

[105] I. P. Dike, O. O. Obembe, and F. E. Adebiyi, "Ethnobotanical survey for potential anti-malarial plants in south-western Nigeria," Journal of Ethnopharmacology, vol. 144, no. 3, pp. 618-626, 2012.

[106] M. S. Traore, M. A. Baldé, M. S. T. Diallo et al., "Ethnobotanical survey on medicinal plants used by Guinean traditional 
healers in the treatment of malaria," Journal of Ethnopharmacology, vol. 150, no. 3, pp. 1145-1153, 2013.

[107] S. Kankara, M. Ibrahim, M. Mustafa, and R. Go, "Ethnobotanical survey of medicinal plants used for traditional maternal healthcare in Katsina State, Nigeria," South African Journal of Botany, vol. 97, pp. 165-175, 2015.

[108] N. I. Mongalo and T. J. Makhafola, "Ethnobotanical knowledge of the lay people of Blouberg area (Pedi tribe), Limpopo Province, South Africa," Journal of Ethnobiology and Ethnomedicine, vol. 14, no. 1, p. 46, 2018.

[109] M. H. Yetein, L. G. Houessou, T. O. Lougbégnon, O. Teka, and B. Tente, "Ethnobotanical study of medicinal plants used for the treatment of malaria in plateau of Allada, Benin (West Africa)," Journal of Ethnopharmacology, vol. 146, no. 1, pp. 154-163, 2013.

[110] R. Muganga, L. Angenot, M. Tits, and M. Frédérich, “Antiplasmodial and cytotoxic activities of Rwandan medicinal plants used in the treatment of malaria," Journal of Ethnopharmacology, vol. 128, no. 1, pp. 52-57, 2010.

[111] S. D. Karou, T. Tchacondo, M. A. Djikpo Tchibozo et al., "Ethnobotanical study of medicinal plants used in the management of diabetes mellitus and hypertension in the central region of Togo," Pharmaceutical Biology, vol. 49, no. 12, pp. 1286-1297, 2011.

[112] H. E. Gbekley, S. I. D. Karou, G. Katawa et al., "Ethnobotanical survey of medicinal plants used in the management of hypertension in the maritime region of Togo," African Journal of Traditional, Complementary and Alternative Medicines, vol. 15, no. 1, pp. 85-97, 2018.

[113] F. Balogun and A. Ashafa, "A review of plants used in south African traditional medicine for the management and treatment of hypertension," Planta Medica, vol. 85, no. 4, pp. 312-334, 2019.

[114] A. A. Adeyemi, A. A. Gbolade, J. O. Moody, O. O. Ogbole, and M. T. Fasanya, "Traditional anti-fever Phytotherapies in Sagamu and Remo north districts in Ogun state, Nigeria," Journal of Herbs Spices \& Medicinal Plants, vol. 16, no. 3-4, pp. 203-218, 2010.

[115] F. Mesfin, S. Demissew, and T. Teklehaymanot, "An ethnobotanical study of medicinal plants in Wonago Woreda, SNNPR, Ethiopia," Journal of Ethnobiology and Ethnomedicine, vol. 5, no. 1, p. 28, 2009.

[116] A. Gbolade, "Ethnobotanical study of plants used in treating hypertension in Edo state of Nigeria," Journal of Ethnopharmacology, vol. 144, no. 1, pp. 1-10, 2012.

[117] D. J. Simbo, "An ethnobotanical survey of medicinal plants in Babungo, Northwest Region, Cameroon," Journal of Ethnobiology and Ethnomedicine, vol. 6, no. 1, p. 8, 2010.

[118] D. Motlhanka and G. P. Nthoiwa, "Ethnobotanical survey of medicinal plants of Tswapong north, in eastern Botswana: a case of plants from Mosweu and Seolwane villages," European Journal of Medicinal Plants, vol. 3, no. 1, pp. 10-24, 2013.

[119] O. S. Olorunnisola, G. Bradley, and A. J. Afolayan, "Ethnobotanical information on plants used for the management of cardiovascular diseases in Nkonkobe Municipality, South Africa," Journal of Medicinal Plants Research, vol. 5, no. 17, pp. 4256-4260, 2011.

[120] S. S. Semenya and M. J. Potgieter, "Kirkia wilmsii: a Bapedi treatment for hypertension," South African Journal of Botany, vol. 100, pp. 228-232, 2015.
[121] C. A. Pallant, A. D. Cromarty, and V. Steenkamp, "Effect of an alkaloidal fraction of Tabernaemontana elegans (Stapf.) on selected micro-organisms," Journal of Ethnopharmacology, vol. 140, no. 2, pp. 398-404, 2012.

[122] A. Paterna, S. E. Gomes, P. M. Borralho, S. Mulhovo, C. M. P. Rodrigues, and M.-J. U. Ferreira, "Vobasinyl-Iboga Alkaloids from Tabernaemontana elegans: Cell Cycle Arrest and Apoptosis-Inducing Activity in HCT116 Colon Cancer Cells," Journal of Natural Products, vol. 79, no. 10, pp. 2624-2634, 2016.

[123] A. S. Odeyemi, G. Bradley, and S. Semenya, "Medicinal uses, phytochemistry and pharmacological properties of Elaeodendron transvaalense," Nutrients, vol. 11, no. 3, p. 545, 2019.

[124] E. Díaz-de-Cerio, V. Verardo, A. M. Gómez-Caravaca, A. Fernández-Gutiérrez, and A. Segura-Carretero, "Health effects of Psidium guajava L. leaves: an overview of the last decade," International Journal of Molecular Sciences, vol. 18, no. 4, 2017.

[125] R. M. P. Gutiérrez, S. Mitchell, and R. V. Solis, "Psidium guajava: a review of its traditional uses, phytochemistry and pharmacology," Journal of Ethnopharmacology, vol. 117, no. 1, pp. 1-27, 2008.

[126] R. B. Singh, S. S. Rastogi, N. K. Singh, S. Ghosh, S. Gupta, and M. A. Niaz, "Can guava fruit intake decrease blood pressure and blood lipids?," Journal of Human Hypertension, vol. 7, no. 1, pp. 33-38, 1993.

[127] E. Irondi, S. Agboola, G. Oboh, A. Boligon, M. Athayde, and F. Shode, "Guava leaves polyphenolics-rich extract inhibits vital enzymes implicated in gout and hypertension in vitro," Journal of Intercultural Ethnopharmacology, vol. 5, no. 2, pp. 122-130, 2016.

[128] J. Mensah, R. Okoli, A. Turay, and E. Ogie-Odia, "Phytochemical analysis of medicinal plants used for the management of hypertension by Esan people of Edo state, Nigeria," Ethnobotanical Leaflets, vol. 2009, no. 10, p. 7, 2009.

[129] A. O. Ademiluyi, G. Oboh, O. B. Ogunsuyi, and F. M. Oloruntoba, "A comparative study on antihypertensive and antioxidant properties of phenolic extracts from fruit and leaf of some guava (Psidium guajava L.) varieties," Comparative Clinical Pathology, vol. 25, no. 2, pp. 363-374, 2016.

[130] B. Huisamen, C. George, S. Genade, and D. Dietrich, "Cardioprotective and anti-hypertensive effects of Prosopis glandulosa in rat models of pre-diabetes: cardiovascular topics," Cardiovascular Journal Of Africa, vol. 24, no. 2, p. 10, 2013.

[131] J. P. Dzoyem, L. J. McGaw, and J. N. Eloff, "In vitro antibacterial, antioxidant and cytotoxic activity of acetone leaf extracts of nine under-investigated Fabaceae tree species leads to potentially useful extracts in animal health and productivity," BMC Complementary and Alternative Medicine, vol. 14, no. 1, p. 147, 2014.

[132] S. Ramesar, H. Baijnath, T. Govender, and I. Mackraj, "Angiotensin I-converting enzyme inhibitor activity of nutritive plants in KwaZulu-Natal," Journal of Medicinal Food, vol. 11, no. 2, pp. 331-336, 2008.

[133] N. el Imane Harrat, S. Louala, F. Bensalah, F. Affane, H. Chekkal, and M. Lamri-Senhadji, "Anti-hypertensive, anti-diabetic, hypocholesterolemic and antioxidant properties of prickly pear nopalitos in type 2 diabetic rats fed a high-fat diet," Nutrition \& Food Science, vol. 49, no. 3, pp. 476-490, 2019. 
[134] S. Mlala, O. Oyedeji, and B. Nkeh-Chungag, Chemical Constituents and Biological Studies of Tagetes Minuta L. and Rauvolfia Caffra Sond, University of Fort Hare, 2015.

[135] J. Kennedy and M. Thorley, "Pharmacognosy, phytochemistry, medicinal plants (2nd ed.)," Carbohydrate Polymers, vol. 42, no. 4, pp. 428-429, 2000.

[136] A. T. Girgih, R. He, S. Malomo, M. Offengenden, J. Wu, and R. E. Aluko, "Structural and functional characterization of hemp seed (Cannabis sativa L.) protein-derived antioxidant and antihypertensive peptides," Journal of Functional Foods, vol. 6, pp. 384-394, 2014.

[137] R. Mao, P. Xia, Z. He et al., "Identification of seeds based on molecular markers and secondary metabolites in Senna obtusifolia and Senna occidentalis," Botanical Studies, vol. 58, no. 1, p. 43, 2017.

[138] R. A. Schultz, T. S. Kellerman, and H. Van den Berg, "The role of fluorescence polarization immuno-assay in the diagnosis of plant-induced cardiac glycoside poisoning livestock in South Africa," The Onderstepoort Journal of Veterinary Research, vol. 72, no. 3, pp. 189-201, 2005. 